\title{
Correction to: Study of high viscous multiphase flow in a horizontal pipe
}

Yahaya D. Baba ${ }^{1,2}$ - Aliyu M. Aliyu ${ }^{3}$ - Archibong-Eso Archibong ${ }^{1,3}$. Almabrok A. Almabrok ${ }^{4}$ A. I. Igbafe $^{2}$

Published online: 2 December 2017

(C) Springer-Verlag GmbH Germany, part of Springer Nature 2017

\section{Correction to: Heat Mass Transfer}

https://doi.org/10.1007/s00231-017-2158-5

The article title should be Study of high viscous multiphase flow in a horizontal pipe.

The online version of the original article can be found at https://doi.org/ 10.1007/s00231-017-2158-5.

Yahaya D. Baba

y.baba9550@gmail.com

1 Oil and Gas Engineering Centre, Cranfield University, Cranfield, UK

2 Chemical/Petroleum Engineering Department, Afe Babalola University, PMB 5454, Ado-Ekiti, Nigeria

3 School of Mechanical Engineering, Pusan National University, 609-735 Busan, Republic of Korea

4 Department of Petroleum Engineering, Faculty of Engineering, Sirte University, Sirte, Libya 